\title{
Technology Evolution of China's Export of Renewable Energy Products
}

\author{
Xuping Cao ${ }^{1,2,3, *}$, Aroskar Rajarshi ${ }^{2}$ and Juxi Tong ${ }^{1,3}$ \\ 1 School of Economics and Management, Changshu Institute of Technology, Changshu 215500, China; \\ juxit@cslg.edu.cn \\ 2 School of Business, University of Wisconsin-Eau Claire, Eau Claire, WI 54702, USA; AROSKAR@uwec.edu \\ 3 Suzhou Agricultural Modernization Research Center, Changshu Institute of Technology, \\ Changshu 215500, China \\ * Correspondence: 201000065@cslg.edu.cn; Tel.: +86-512-5225-1771
}

Received: 23 July 2018; Accepted: 17 August 2018; Published: 19 August 2018

\begin{abstract}
With the increasing scarcity of traditional energy sources, global warming and environmental degradation, the increased use of renewable energy (RE) has become an effective path for sustainable development. Therefore, countries are paying more and more attention to the development of the RE industry, and the world trade in renewable energy products (REPs) is developing rapidly. First of all, this paper defines REPs, refines the scope of REPs, and proposes the "Equalization Technology Classification" method for the technology classification of REPs. Second, based on the United Nations Comtrade (COMTRADE) data, the export technology structure of China's REPs from 2007 to 2016 was empirically measured. Finally, a comparative study was conducted on the renewable energy product (REP) export technologies of major REP exporting countries (or regions) in the world. We found that (1) China's exports of REPs are mainly medium-high and medium technical complexity products, and that there are few high technical complexity products; (2) the export technology structure of China's REPs is deteriorating, and its overall technical level is in the middle of the global industrial value chain. The export technology of China's REPs has a gap compared with that of Denmark, Hong Kong China, and Singapore; (3) the technological competition of the world's REPs is becoming increasingly fierce. The growth rates of REP technologies in South Korea, Japan, and Malaysia's REPs are significantly higher than that of China.
\end{abstract}

Keywords: technical complexity index; renewable energy products; China

\section{Introduction}

Renewable energy (RE) is a non-traditional energy source that includes solar energy, wind energy, biomass energy, and nuclear fusion energy [1]. It is widely available, renewable, low-carbon and has minimal environmental impact [2]. With the increasing scarcity of traditional energy sources, global warming, and environmental degradation, the increased use of RE has become an effective path for sustainable development [3,4]. At present, RE accounts for a small proportion of the world's energy use [5]. However, with the continuous advancement of the RE utilization technology, it is an irresistible trend to replace traditional energy sources with RE [6,7]. With a large population, China is one of the world's largest energy consumers [8]. As early as 2010, the RE industry was listed by China as one of the seven strategic emerging industries in the country [9]. In 2016, China's "13th Five-Year Plan for RE Development" proposed to accelerate the establishment of a clean, low-carbon, safe and efficient modern energy system, and to achieve the goal of non-fossil energy accounting for $15 \%$ of primary energy consumption by 2020 [10]. 
In recent years, China's RE industry has developed rapidly. Statistics show that China has become the world's largest RE investor, owner of RE vehicles, and REP producer and consumer country [11]. Correspondingly, the export of REPs has also developed rapidly. According to COMTRADE data, China's REP exports in 2016 reached $\$ 83.40$ billion, accounting for $24.31 \%$ of the world's export share, ranking first in the world [12].

However, China's economy has entered a new stage of "coming to a quality revolution made in China", and the quality of export commodities is more important than quantity [13]. In recent years, China has actively integrated into the process of economic globalization by taking advantage of its low labor resources, and many industries have already led the world in export volume [14]. Economic theory and international development experience show that sustainable economic growth is inseparable from the continuous optimization of export technology structure [15]. Fan et al. (2009) [16] found that the proportion of low value-added products in China's export structure showed a downward trend, and medium-level products gradually became the main export products. It is concerningas to whether the evolutionary trend of China's REP exports is the same as that of China's export technology. To this end, this paper will empirically measure the changes in export technology of China's REPs.

Previous literature studies have focused on the export competitiveness, export challenges, and export technology measures of REPs [17]. Wei et al. (2016) [18] found that RE equipment is China's second largest export-oriented environmental product, and that its export share is second only to wastewater treatment products. Solar photovoltaic cellsare one of the world's important export REPs. Zhao et al. (2017) [19] found that most of the world's solar photovoltaic cell exporters are located in East Asia and Southeast Asia, and that the international trade intensity of solar photovoltaic cell is growing. Fu et al. (2013) [20] found that the export of China's REPs to the US, EU, and Japan markets showed a rapid growth. However, Fu et al. (2013) [20] only analyzed the export of 4-digit Harmonized Commodity Description and Coding System (HS) coded products. Four-digit HS-coded products contain many non-renewable energy product categories, and the definition of REPs is not precise enough. This paper defines the scope of REPs from the 6-digit HS code, and partially eliminates or supplements the Fu et al. (2013) [20] classified products. Additionally, there is no clear authoritative definition of REPs. This study defines REPs as equipment and related products that provide services for the efficient use of RE, and the development of RE industries.

Although China's REPs have achieved good export performance, the country still faces many problems or challenges, such as lack of high technology, unsustainable government subsidy policies, and unpredictable global trade environment [21-25]. Most of the global RE dispute cases since 2007 are related to China [26]. For example, the solar photovoltaic dispute between China and USA, since 2012 has had a serious negative impact on China's solar photovoltaic industry and its exports $[27,28]$. This fully exposes the overcapacity of low technology products in China's RE industry [29]. This article will focus on the export technology structure of China's REPs.

For the measurement of export technology, Guan et al. (2002) [30] proposed the technology added value method. Lall et al. (2006) [31] proposed a complex index method, and Du et al. (2007) [32] revised the method. Hausmann et al. (2005) [33] proposed the use of "product-relevant income levels" $(P R O D Y)$ to determine the level of product labor productivity, also known as technical complexity index. What these methods have in common is that they first determine the technical level of a single product, then they calculate the overall technical level of the economy, and assign the technology content of the product to the weighted sum of the income levels of countries (or regions). The difference between these methods is the assignment weight. The valuation weights of Guan et al. (2002) [30] and Lall et al. (2006) [31] are the world share of various products exported by various countries. $\mathrm{Du}$ et al. (2007) [32] revised the weight of the method to the world share of various types of products produced by various countries. The valuation weights of Hausmann et al. (2005) [33] are the export comparative advantage index after the standardization of various products in various countries. In comparison, the application of the technique complexity method of Hausmann et al. 
(2005) [33] is more common, and the research data is more acquirable. These application areas involve cultural and creative industries, manufacturing, agriculture, etc., but there is a lack of research on REPs export technology [34-36]. To this end, this paper chooses the technical complexity index of Hausmann et al. (2005) [33] to empirically measure the dynamic changes of China's REP export technology. The Hausmann et al. (2005) [33] method does not classify PRODY values. This study proposes a method called "Equalization Technology Classification" that divides all REPs into five technical levels: high, medium-high, medium, medium-low, and low according to the PRODY value. This method facilitates a clearer REP technology analysis and international comparison.

Different classification criteria for PRODY values will have different effects on the conclusions of the study. The main classification methods of the previous literature are the "Experience Sorting Method" of Tang (2012) [37], the "Technical Fixed Classification" of Zhu et al. (2009) [38], and the "Optimal Segmentation Method" of Wei (2015) [15]. The method of Tang (2012) [37] classifies the PRODY values according to the author's experience, ensuring that the technology classifications are as normal as possible, and the classification results of different scholars may be different. The method of Zhu et al. (2009) [38] ignores the fact that technology changes over time. The method of Wei (2015) [15] sorts $P R O D Y$ data, and then determines the number of categories according to the needs, which are also likely to cause people to subjectively change the technology differences between samples. To this end, the "Equilibrium Technology Method" proposed in this paper emphasizes objectivity and will avoid the classification results being influenced by time change and human experience.

The review shows that technological innovation is one of the important factors affecting the sustainable development of China's RE industry. However, there is little research literature on the structural changes in export technologies for REPs. Moreover, the definition and technology classification of REPs need to be further improved [20]. To this end, this paper is based on previous literature research [20], to first refine the scope of REPs further. Then, this paper uses the technical complexity index to empirically measure the dynamic changes of China's REP export technology. In order to ensure the objectivity of product technical complexity classification, this paper proposes the "Equalization Technology Classification" method.

\section{Methods and Data}

\subsection{Methods}

The export complexity method proposed by Hausmann et al. (2005) [33] uses international trade data to replace hard-to-find research and development (R\&D) data for various types of products in countries (or regions) around the world. The basic assumption of this method is that the more technical a class of products that are being exported from high-income countries, the higher the technical complexity of the product. This method does not consider other factors such as trade friction and intervention [39]. In the global manufacturing value chain, developed countries are generally in the process of high value-added value such as R\&D design, brand, and key parts production, while developing countries are more involved in low value-added links such as raw material supply and assembly. The status of countries in the global value chain will be reflected in the technological structure of the products that they export. This method combines the per capita income of countries (or regions) with exports. The technological content of the export products of these countries (or regions) in the global value chain can be measured. The method used in this paper consisted of three steps: calculating the technical complexity of various REPs, classifying the technical complexity of different REPs, and calculating the overall technical level of each country (or region).

(1) The equation for the technical complexity of REP export. The $P R O D Y_{k}$ is the export technical complexity of the category $k$ export REPs at the world level. The equation [33] for $P R O D Y_{k}$ is:

$$
\operatorname{PRODY}_{k}=\sum_{j} \frac{x_{j k} / X_{j}}{\sum_{j} x_{j k} / X_{j}} \times Y_{j}
$$


The notations in Equation (1) and their meanings are as follows:

$j \quad$ the $j$ th REPs exporting country (or region)

$k \quad$ the category of export REPs

$X_{j} \quad$ the total exports of all REPs in the country (or region) $j$

$x_{j k} \quad$ the export value of category $k$ REPs of country (or region) $j$

$Y_{j} \quad$ the per capita gross domestic product (GDP) of country (or region) $j$

$\mathrm{PRODY}_{k}$ the export technical complexity of the category $k$ export REPs at the world level

(2) The principle of the "Equalization Technology Classification" method: the basic principle of this method is to ensure that the PRODY value difference of adjacent technology grade products is equal, and that there is no limit to the number of products that are owned by each grade.

First, the calculated PRODY values of $n$ type REPs were arranged from smallest to largest, into an ordered sample $\left(t_{1}, t_{2}, t_{3}, \ldots, t_{n}\right)$, where $t_{1}$ is the smallest and $t_{n}$ is the largest.

Second, it was assumed that the REP technology was divided into $m$ grades, and that the PRODY value difference of the adjacent technology grade products was $D$. The equation for $D$ is:

$$
D=\frac{t_{n}-t_{1}}{m}
$$

Finally, the technology classification criteria for REPs were calculated. The standards for the 1,2, $3, \ldots, m$ levels of REPs were PRODY $\leq t_{1}+D, t_{1}+D<$ PRODY $\leq t_{1}+2 D, t_{1}+2 D<$ PRODY $\leq t_{1}+3 D$, $\ldots t_{n}-D<P R O D Y$. This method can determine the technology classification standards of all REPs in the world in a certain period of time. According to this standard, it is possible to clearly know how many high technical REPs are exported by a country (or region).

(3) The calculation method of overall export technical level (which we call EXPY) of REPs. Assume that the overall export technical level of REPs in country (or region) $j$ is EXPY $Y_{j}$, and its equation [35] is:

$$
\operatorname{EXPY}_{j}=\sum_{k} \frac{x_{j k}}{X_{j}} \times P R O D Y_{k}
$$

The calculated EXPY values are mainly used to compare the overall technical level of REPs in countries (or regions).

\subsection{Data}

\subsubsection{Scope Definition for Reps}

At present, there is no uniform authority defining standard for the range of REPs. Fu et al. (2013) [20] divides REPs into five categories: nuclear energy, wind energy, solar energy, biomass energy, and smart grid, and 14 subdivided 4-digit HS code products. However, some 4-digit code connotation 6-digit products do not belong to the energy industry, while smart grids are mainly traditional power facilities. Based on an in-depth study of the HS code and the China Import and Export Tariff, this study revised the classification of Fu et al. (2013). This paper divided REPs into fourcategories: nuclear energy, wind energy, solar energy, and biomass energy. Each category contained many sub-categories. The detailed categories of REPs and their HS codes are shown in Table 1. 
Table 1. The categories of renewable energy products (REPs) and their Harmonized Commodity Description and Coding System (HS) codes.

\begin{tabular}{|c|c|c|}
\hline Product Category & Commodity Code & Commodity Descriptions \\
\hline \multirow{4}{*}{ Nuclear energy products } & 8401 & $\begin{array}{l}\text { Nuclear reactor; unirradiated fuel element (heat release element) of nuclear } \\
\text { reactor; isotope separation machine and device; other internal components }\end{array}$ \\
\hline & 8402 & $\begin{array}{l}\text { Steam boiler (except for hot water boilers for central heating that can } \\
\text { generate low-pressure steam); superheated water boiler }\end{array}$ \\
\hline & 8404 & $\begin{array}{l}\text { Boiler auxiliary equipment (for example, economizer, superheater, ash } \\
\text { remover, gas recovery); condenser for steam or steam power plant }\end{array}$ \\
\hline & 841950 & $\begin{array}{l}\text { Nuclear reactor dedicated heat exchanger; steam generator (dedicated to } \\
\text { the generation of heat in a nuclear reactor into steam) }\end{array}$ \\
\hline \multirow{9}{*}{ Wind energy products } & 841239 & Other pneumatic power units \\
\hline & 850231 & Wind power equipment \\
\hline & 850300 & Wind power equipment parts \\
\hline & 903289 & Wind power equipment controller \\
\hline & 722840 & Forging tool round steel (mainly used for wind energy) \\
\hline & 853710 & Wind energy controller \\
\hline & 841480 & Air compressor accessories (air duct) \\
\hline & 841490 & Air compressor parts (impellers, blades, etc.) \\
\hline & 392099 & Plastic sound board on the wind blade \\
\hline \multirow{9}{*}{ Solar products } & 854140 & Solar cell; light emitting diode; other photosensitive semiconductor device \\
\hline & 850239 & Generator set that relies on renewable energy (RE) to produce electricity \\
\hline & 841919 & Solar water heaters \\
\hline & 850440 & Solar inverter, converter, regulated power supply \\
\hline & 854370 & Solar power station \\
\hline & 850720 & Lead-acid cell for solar energy \\
\hline & 940540 & Solar-related lighting device \\
\hline & 901390 & Solar heliostat parts \\
\hline & 280461 & Polysilicon \\
\hline \multirow{6}{*}{ Biomass energy products } & 440130 & Sawdust, waste and other biomass \\
\hline & 841620 & Gas burners, burners, etc. \\
\hline & 850220 & Natural gas power generation unit, generator \\
\hline & 8405 & Gas, acetylene and similar hydrolyzed gas generators \\
\hline & 847930 & Granulator; wood extruder; biomass mill, etc. \\
\hline & 840790 & Biogas engine \\
\hline
\end{tabular}

Note: The data comes fromthe United Nations Comtrade (COMTRADE) database [12], and the product description is streamlined.

As can be seen from Table 1, the five categories of products contained a total of 28 categories of sub-product categories. Since some of the 4-digit code products contained only a part of the 6-digit code products belonging to REPs, the sub-product categories in Table 1 included both HS 4-digit and HS 6-digit code products.

\subsubsection{Sample Selection and Data Source}

This article selected Austria, Belgium, Brazil, Canada, China, Hong Kong China, Czech Republic, Denmark, Finland, France, Germany, Hungary, India, Italy, Japan, Malaysia, Mexico, Netherlands, Poland, South Korea, Romania, Russia, Singapore, Spain, Sweden, Switzerland, Thailand, the United Kingdom, and USA as analytical samples. These 29 samples are the world's major REPs exporting countries (or regions) from 2007 to 2016 (Table A1). The COMTRADE data showed that their REPs exports accounted for more than $90 \%$ of the world's total, and they were highly representative samples [12]. The per capita gross domestic product (GDP) of each country (region) was derived from the World Bank database and was converted to purchasing power parity (PPP) (Table A2) [40]. The PPP in this article used the "Constant 2011 International \$" standard. In order to ensure the 
consistency in research data, the export data of this paper were all from the COMTRADE database, and the commodity code adopted the HS2007 standard.

\section{Results}

\subsection{Division of Technology Structure Standards of Various Products}

Using Equation (1), the annual average of PRODY (Table A3) for REPs from 2007 to 2016 was calculated. Then, the PRODY values were divided into five grades by using the "Equalization Technique Classification" method. The result is a classification of REPs into high technical complexity products $(\$ 36,858<P R O D Y)$, medium-high technical complexity products $(\$ 30,550<$ PRODY $\leq \$ 36,858)$, medium technical complexity products $(\$ 32,653<$ PRODY $\leq \$ 34,755)$, medium-low technical complexity products $(\$ 32,873<P R O D Y \leq \$ 32,653)$, and low technical complexity products $(\$ 28,448<P R O D Y \leq \$ 30,550)$ (Table 2). The technology structure distribution of the world'sREPs is shown in Table 2.

Table 2. The technology structure distribution of the world's REPs.

\begin{tabular}{|c|c|c|}
\hline Technical Complexity Classification & Classified Standard $/ \$$ & Product HS Code \\
\hline High technicalcomplexity products & $36,858<$ PRODY & $\begin{array}{l}841620,722840,850239,850231, \\
392099,280461,850220,841239\end{array}$ \\
\hline Medium-high technicalcomplexity products & $34,755<P R O D Y \leq 36,858$ & $\begin{array}{c}841950,440130,854140,847930 \\
841490,8405,850440\end{array}$ \\
\hline Medium technicalcomplexity products & $32,653<P R O D Y \leq 34,755$ & $841480,901390,940540,854370$ \\
\hline Medium-low technical complexity products & $30,550<P R O D Y \leq 32,653$ & $\begin{array}{c}8404,850300,850720,8401 \\
841919,903289,853710\end{array}$ \\
\hline Low technicalcomplexity products & $28,448<P R O D Y \leq 30,550$ & 840790,8402 \\
\hline
\end{tabular}

Note: The raw data of the calculation results are from the COMTRADE database.

As can be seen from Table 2, the number of high technical complexity products was the highest, up to eight. Products with medium-high, medium-low technical complexity each had seven categories. There were four kinds of technical complexity products, and only two kinds of low technical complexity products.

\subsection{Dynamic Distribution of Technology Structure of China's REPS}

According to the classification in Table 2, the export shares of different technology classifications of China's REPs from 2007 to 2016 are shown in Table 3.

Table 3. Dynamic distribution of export technology structure of China's REPs.

\begin{tabular}{|c|c|c|c|c|c|}
\hline Years & $\begin{array}{l}\text { High-Tech } \\
\text { Complexity } \\
\text { Ratio/\% }\end{array}$ & $\begin{array}{c}\text { Medium-High } \\
\text { Technical Complexity } \\
\text { Ratio/\% }\end{array}$ & $\begin{array}{l}\text { Medium-Tech } \\
\text { Complexity } \\
\text { Ratio/\% }\end{array}$ & $\begin{array}{c}\text { Medium-Low } \\
\text { Technical Complexity } \\
\text { Ratio/ } \%\end{array}$ & $\begin{array}{c}\text { Low-Tech } \\
\text { Complexity } \\
\text { Ratio/\% }\end{array}$ \\
\hline 2007 & 6.28 & 51.60 & 22.85 & 15.90 & 3.37 \\
\hline 2008 & 6.11 & 51.54 & 21.04 & 15.91 & 5.39 \\
\hline 2009 & 4.68 & 52.42 & 20.15 & 16.21 & 6.55 \\
\hline 2010 & 3.61 & 60.27 & 18.84 & 13.54 & 3.73 \\
\hline 2011 & 4.32 & 55.86 & 21.80 & 13.97 & 4.05 \\
\hline 2012 & 4.88 & 49.69 & 24.75 & 16.85 & 3.84 \\
\hline 2013 & 4.90 & 46.90 & 28.04 & 16.85 & 3.31 \\
\hline 2014 & 4.16 & 46.24 & 30.03 & 16.63 & 2.94 \\
\hline 2015 & 3.48 & 45.74 & 31.70 & 16.51 & 2.58 \\
\hline 2016 & 3.37 & 42.58 & 33.71 & 17.71 & 2.63 \\
\hline Annual Average & 4.58 & 50.28 & 25.29 & 16.01 & 3.84 \\
\hline
\end{tabular}

Note: The raw data of the calculation results are from the COMTRADE database. 
As can be seen from Table 3, China's REP exports are dominated by medium-high technical complexity products. From 2007 to 2016, the average annual export share of medium-high technical complexity products accounted for $50.28 \%$. However, the average annual export share of China's high technical complex REPs was only 4.58\% (Table 3). Additionally, the export technology structure of China's REPs is deteriorating. From the trend of change, the export shares of high and medium-high technical complex products showed a significant decline. The proportion of cumulative exports of the two types of products decreased from $57.88 \%$ in 2007 to $45.95 \%$, a drop of $20.61 \%$ (Table 3). In contrast, the export share of medium and medium-low technical complexity products is gradually increasing. In 2016, China's REP export technical complexity below the medium-high level accounted for $54.04 \%$ (Table 3). The higher the technical complexity index of export REPs, the greater the added value of their exports. Therefore, it is urgent to optimize the export technology structure of China's REPs.

\subsection{International Comparison of Export Technologies for REPs}

Using Equation (3), the EXPYs for REPs in 29 countries (or regions) from 2007 to 2016 were calculated. This paper selects 14 countries (or regions) with the highest annual average EXPY value for comparative study. These countries (or regions) are Hong Kong China, Singapore, the Netherlands, Switzerland, Austria, China, Malaysia, Finland, USA, South Korea, Japan, Sweden, Germany, and Denmark (Table 4). The comparison data of the EXPY changes of REPs in 14 countries (or regions) from 2007 to 2016 are shown in Table 4. 
Table 4. Changes in overall export technical level (EXPY) values of REPs in 14 countries (or regions).

\begin{tabular}{|c|c|c|c|c|c|c|c|c|c|c|c|c|c|c|}
\hline \multirow{2}{*}{ Years } & \multicolumn{14}{|c|}{ EXPY Value of REPs/\$ } \\
\hline & Denmark & Hong Kong China & Singapore & Netherlands & ds Switzerland & Austria & China & Malaysia & Finland & USA & South Korea & Japan & Sweden & Germany \\
\hline 2008 & 32,572 & 34,160 & 34,226 & 34,204 & 34,756 & 34,496 & 33,557 & 32,954 & 34,081 & 34,119 & 33,259 & 33,342 & 34,310 & 33,485 \\
\hline 2009 & 31,665 & 32,810 & 32,848 & 32,761 & 33,534 & 32,831 & 32,106 & 31,486 & 32,905 & 32,834 & 31,722 & 32,073 & 33,103 & 32,232 \\
\hline 2011 & 36,908 & 35,340 & 34,700 & 34,222 & 34,259 & 34,556 & 34,479 & 33,846 & 34,713 & 34,179 & 34,406 & 34,174 & 34,468 & 34,018 \\
\hline 2012 & 35,994 & 35,583 & 34,871 & 34,571 & 34,319 & 34,701 & 34,815 & 34,625 & 34,263 & 34,306 & 34,456 & 34,593 & 34,611 & 34,491 \\
\hline 2013 & 37,006 & 36,087 & 35,035 & 34,807 & 34,548 & 34,432 & 35,170 & 35,153 & 34,548 & 34,383 & 34,992 & 34,747 & 34,242 & 34,685 \\
\hline 2014 & 37,413 & 36,616 & 35,646 & 35,513 & 34,937 & 34,751 & 35,554 & 35,851 & 34,797 & 34,993 & 35,793 & 35,287 & 34,720 & 35,096 \\
\hline 2015 & 38,652 & 37,105 & 36,694 & 36,075 & 35,288 & 35,529 & 36,110 & 37,189 & 35,253 & 35,409 & 36,150 & 35,945 & 34,724 & 35,762 \\
\hline
\end{tabular}

Note: The raw data of the calculation results are from the COMTRADE database. 
As can be seen from Table 4, (1) In 2007-2016, the annual average of EXPY of REPs in Denmark ranked first in the world, and Hong Kong China ranked second. The difference in EXPY between the remaining 12 countries was not large. In Denmark, for example, the reason for its high EXPY value is that its high technical complexity index product 850231 (wind power generation equipment) has a high proportion of exports and is highly competitive in the world. In 2016, the export volume of Danish 850231 products reached $\$ 3.17$ billion, accounting for $42.99 \%$ of the total export share of 29 countries (or regions) [5]. Denmark is a veritable wind power kingdom, with the highest per capita RE consumption index, nearly 5000 wind power plants, and the strongest wind power technology. In 2015, the annual average coverage of wind power in Denmark reached 42\% [41]. Denmark plays a pivotal role in the international wind power and equipment export market.

(2) From 2007 to 2016, the overall technology of China's REPs is at a medium technical complexity index level, and there is still a certain gap compared with Denmark, Hong Kong China, and Singapore. China's main export product categories 854140 (solar cells) and 850440 (inverters) belong to the medium-high technical complexity index products, 940540 (solar power station), and 854370 (solar lighting equipment) belong to the category of medium technical complexity index products.

(3) According to the trend of change, the EXPY of China's REPs has shown a rapid growth trend. The EXPY value increased from $\$ 33,610$ in 2007 to $\$ 36,378$ in 2016 (Table 4), indicating that the overall technical level of China's REPs is constantly improving. It is worth noting that the EXPY values of all major REPs exporting countries (or regions) are growing, but the growth rates of EXPY values in South Korea, Japan, and Malaysia's REPs are significantly higher than that of China. In 2016, the EXPY values of these three countries exceeded China's. These phenomena fully demonstrate that the technological competition of the world's REPs is increasingly fierce.

\section{Discussions}

(1) This paper puts forward some inspirational suggestions to promote the technological progress of China's RE industry. First, the low proportion of high technical complex exports restricts the overall technical level of China's REPs. China's REP manufacturers need to abandon short-term market interests, strengthen investment in talent and technology research, and strive to enhance its position in the global RE industry value chain. Second, the form of export trade is too singular and easily causes international trade friction. Therefore, China's REP producers should actively expand cooperation with leading technology countries, such as the docking of RE technology standards, cooperative research and development (R\&D) of RE equipment, exchange of REP technology talents, etc. Third, China's REP producers need more "going out", making full use of foreign resources and technology.

(2) The definition of the scope of REPs has a greater impact on the conclusions of the study. The REPs belong to the category of environmental products. At present, the authoritative definition of environmental products has only been discussed by two international organizations, the Asia-Pacific Economic Cooperation (APEC) and the Organization for Economic Co-operation and Development (OECD), but the differences between the two standards are still large. In the future, this research field deserves further exploration.

(3) Different classification methods of $P R O D Y$ values will also affect the conclusion of the study. This study uses the "Equalization Technology Classification" method, and if other methods are used, the research conclusions will be different. Therefore, the classification of technology structure is worthy of further exploration.

(4) The technical complexity index also has limitations. For example, the processing trade factor and the implementation of the technology export restriction policy are not considered. Therefore, the research conclusion is only used as a reference for decisionmaking. Therefore, future improvements and application studies on this method are worth exploring. 


\section{Conclusions}

The possible innovation of this paper is to define REPs, to revise the scope of REPs, and to propose the "Equalization Technology Classification" method for technical complexity index classification. This paper also expands upon the application of the technical complexity index in the field of REP. The technical complexity index has been used to empirically measure China's REP export technology structure from 2007 to 2016.

The study found that China's REP exports are dominated by medium-high and medium technical complexity products. The proportion of high technical complex export REPs is very low, and the overall export technology structure is deteriorating. In 2016, China's REP export technical complexity below the medium-high level accounted for $54.04 \%$. The overall technical level of China's export REPs is at the middle of the global industrial value chain.

Additionally, Denmark has taken the lead in global REP technology by virtue of its wind energy products. The export technology of China's REPs has a certain gap compared with that of Denmark, Hong Kong China and Singapore. The REP technologies of all major REP exporting countries (or regions) are growing, but the growth rates of REP technologies in South Korea, Japan, and Malaysia's REPs are significantly higher than that of China. In short, the technological competition of the world's REPs is increasingly fierce.

Author Contributions: Conceptualization, X.C. and A.R.; Data curation, X.C.; Formal analysis, X.C.; Funding acquisition, A.R. and J.T.; Methodology, X.C.; Project administration, X.C. and J.T.; Resources, X.C., A.R. and J.T.; Supervision, A.R. and J.T.; Writing—original draft, X.C.; Writing-review \& editing, X.C. and A.R.

Funding: This work was supported by Jiangsu Agricultural Development Committee Agricultural Soft Science Research Foundationin China (Grant No. 18ASS036).

Acknowledgments: We are grateful for the comments and criticisms of an early version of this manuscript by the journal's editors and reviewers.

Conflicts of Interest: The authors declare no conflicts of interest.

\section{Abbreviations}

The following abbreviations are used in this manuscript:

RE

Renewable energy

REPS Renewable energy products

REP Renewable energy product

COMTRADE United Nations Comtrade

$R \& D$ Research and development

PPP Purchasing power parity

GDP 


\section{Appendix}

Table A1. The world's major renewable energy products (REPs) exporters from 2007 to 2016.

\begin{tabular}{cc}
\hline Country (or Region) & The Annual Average of Export Value/\$100 Million \\
\hline China & 838.99 \\
Germany & 374.22 \\
USA & 321.62 \\
Japan & 205.69 \\
South Korea & 136.30 \\
Mexico & 124.42 \\
Hong Kong China & 108.89 \\
Italy & 93.78 \\
Malaysia & 78.24 \\
Thailand & 72.62 \\
Netherlands & 69.35 \\
France & 65.52 \\
Singapore & 65.50 \\
United Kingdom & 63.58 \\
Hungary & 61.24 \\
Denmark & 51.54 \\
Spain & 42.99 \\
Canada & 42.33 \\
Poland & 40.93 \\
Belgium & 39.47 \\
Austria & 37.34 \\
Romania & 36.14 \\
Czech Republic & 34.39 \\
Switzerland & 32.43 \\
Sweden & 30.07 \\
India & 28.58 \\
Russia & 25.76 \\
Finland & 19.35 \\
Brazil & 10.80 \\
\hline
\end{tabular}

Note: The data come fromthe COMTRADE database.

Table A2. The gross domestic product (GDP) ${ }^{1}$ per capita of major exporters, based on purchasing power parity (PPP) ${ }^{2}$ from 2007 to 2016.

\begin{tabular}{|c|c|c|c|c|c|c|c|c|c|c|}
\hline \multirow{2}{*}{ Country (or Region) } & \multicolumn{10}{|c|}{ GDP Per Capita/\$ } \\
\hline & 2007 & 2008 & 2009 & 2010 & 2011 & 2012 & 2013 & 2014 & 2015 & 2016 \\
\hline Austria & 43,878 & 44,418 & 42,619 & 43,336 & 44,453 & 44,552 & 44,303 & 44,345 & 44,354 & 44,491 \\
\hline Belgium & 41,623 & 41,619 & 40,356 & 41,086 & 41,249 & 41,046 & 40,928 & 41,384 & 41,723 & 42,095 \\
\hline Brazil & 13,271 & 13,806 & 13,653 & 14,539 & 14,973 & 15,118 & 15,430 & 15,371 & 14,666 & 14,024 \\
\hline Canada & 41,647 & 41,611 & 39,924 & 40,699 & 41,565 & 41,795 & 42,339 & 43,079 & 43,149 & 43,238 \\
\hline China & 7285 & 7948 & 8652 & 9526 & 10,384 & 11,146 & 11,951 & 12,759 & 13,570 & 14,399 \\
\hline Hong Kong China & 45,937 & 46,635 & 45,390 & 48,108 & 50,086 & 50,378 & 51,732 & 52,789 & 53,595 & 54,354 \\
\hline Czech Republic & 28,844 & 29,373 & 27,804 & 28,353 & 28,797 & 28,527 & 28,380 & 29,120 & 30,605 & 31,339 \\
\hline Denmark & 46,374 & 45,866 & 43,383 & 43,998 & 44,403 & 44,337 & 44,564 & 45,057 & 45,459 & 45,991 \\
\hline Finland & 42,467 & 42,575 & 38,868 & 39,848 & 40,684 & 39,913 & 39,428 & 39,018 & 38,942 & 39,659 \\
\hline France & 37,772 & 37,635 & 36,341 & 36,872 & 37,457 & 37,345 & 37,367 & 37,531 & 37,766 & 38,061 \\
\hline Germany & 40,474 & 40,989 & 38,784 & 40,429 & 42,693 & 42,822 & 42,914 & 43,561 & 43,938 & 44,357 \\
\hline Hungary & 23,492 & 23,734 & 22,202 & 22,404 & 22,841 & 22,582 & 23,119 & 24,161 & 25,034 & 25,664 \\
\hline India & 3699 & 3787 & 4050 & 4405 & 4636 & 4828 & 5074 & 5390 & 5754 & 6093 \\
\hline Italy & 38,612 & 37,954 & 35,710 & 36,201 & 36,347 & 35,228 & 34,220 & 33,946 & 34,302 & 34,655 \\
\hline Japan & 36,697 & 36,278 & 34,317 & 35,750 & 35,775 & 36,368 & 37,149 & 37,337 & 37,883 & 38,283 \\
\hline South Korea & 28,014 & 28,588 & 28,643 & 30,352 & 31,229 & 31,777 & 32,549 & 33,426 & 34,178 & 34,986 \\
\hline Malaysia & 20,685 & 20,989 & 20,092 & 21,107 & 21,819 & 22,591 & 23,224 & 24,195 & 25,002 & 25,669 \\
\hline Mexico & 16,044 & 16,008 & 15,012 & 15,535 & 15,923 & 16,324 & 16,316 & 16,460 & 16,672 & 16,832 \\
\hline Netherlands & 46,528 & 47,134 & 45,126 & 45,525 & 46,067 & 45,411 & 45,191 & 45,668 & 46,494 & 47,270 \\
\hline Poland & 19,563 & 20,392 & 20,953 & 21,771 & 22,851 & 23,218 & 23,555 & 24,347 & 25,300 & 26,036 \\
\hline Romania & 17,277 & 19,053 & 17,855 & 17,818 & 18,095 & 18,292 & 19,009 & 19,667 & 20,545 & 21,615 \\
\hline Russia & 22,799 & 24,006 & 22,122 & 23,108 & 24,310 & 25,156 & 25,551 & 25,285 & 24,517 & 24,417 \\
\hline Singapore & 68,423 & 66,037 & 63,688 & 72,105 & 75,013 & 76,029 & 78,549 & 80,305 & 80,892 & 81,443 \\
\hline Spain & 34,330 & 34,164 & 32,653 & 32,507 & 32,068 & 31,109 & 30,679 & 31,195 & 32,291 & 33,320 \\
\hline Sweden & 44,051 & 43,466 & 40,863 & 42,943 & 43,755 & 43,308 & 43,476 & 44,168 & 45,679 & 46,568 \\
\hline Switzerland & 56,269 & 56,756 & 54,806 & 55,866 & 56,184 & 56,150 & 56,536 & 57,218 & 57,264 & 57,428 \\
\hline Thailand & 12,607 & 12,757 & 12,605 & 13,487 & 13,535 & 14,448 & 14,778 & 14,853 & 15,237 & 15,683 \\
\hline United Kingdom & 38,384 & 37,903 & 36,042 & 36,367 & 36,608 & 36,893 & 37,399 & 38,252 & 38,839 & 39,309 \\
\hline USA & 51,011 & 50,384 & 48,558 & 49,373 & 49,791 & 50,520 & 51,008 & 51,932 & 53,029 & 53,445 \\
\hline
\end{tabular}

Note: ${ }^{1}$ The data come from the World Bank; ${ }^{2}$ The PPP uses the "Constant 2011 International \$” standard. 
Table A3. The annual average of PRODY for REPs from 2007 to 2016.

\begin{tabular}{cc}
\hline HS Coding & The Annual Average of PRODY/\$ \\
\hline 8401 & 32,035 \\
8402 & 28,716 \\
8404 & 30,879 \\
8405 & 36,511 \\
280461 & 38,348 \\
392099 & 37,693 \\
440130 & 35,256 \\
722840 & 36,971 \\
840790 & 28,448 \\
841239 & 38,961 \\
841480 & 33,036 \\
841490 & 36,284 \\
841620 & 36,870 \\
841919 & 32,095 \\
841950 & 34,933 \\
847930 & 36,014 \\
850220 & 38,468 \\
850231 & 37,370 \\
850239 & 37,145 \\
850300 & 31,244 \\
850440 & 36,839 \\
850720 & 31,968 \\
853710 & 32,403 \\
854140 & 35,478 \\
854370 & 34,347 \\
901390 & 33,048 \\
903289 & 32,280 \\
940540 & 33,660 \\
\hline
\end{tabular}

Note: The raw data of the calculation results are from the COMTRADE database.

\section{References}

1. Mendonça, H.L.; Van Aduard de Macedo-Soares, T.D.L.; Fonseca, M.V.D.A. Working towards a framework based on mission-oriented practices for assessing renewable energy innovation policies. J. Clean. Prod. 2018, 193, 709-719. [CrossRef]

2. Ruotsalainen, J.; Karjalainen, J.; Child, M.; Heinonen, S. Culture, values, lifestyles, and power in energy futures: A critical peer-to-peer vision for renewable energy. Energy Res. Soc. Sci. 2018, 34, 231-239. [CrossRef]

3. Rada, E.C.; Ragazzi, M.; Cioca, L.I.; Ionescu, G.; Ranieri, E.; Trulli, E. Renewable energy in the Alps: A case study. Qual. Access Success 2017, 18, 151-156.

4. Apostolovic, M.R.; Skokljev, I.A. Energy balances of South East European countries with the emphasis on the influences of renewable energy sources. In Proceedings of the 4th International Symposium on Environment Friendly Energies and Applications (EFEA), Belgrade, Serbia, 14-16 September 2016.

5. Lu, W. Greenhouse gas emissions, energy consumption and economic growth: A panel cointegration analysis for 16 Asian countries. Int. J. Environ. Res. Public Health 2017, 14, 1436. [CrossRef] [PubMed]

6. Obadia, K.; Zhang, L.; Witness, G. The potential renewable energy for sustainable development in Tanzania: A review. Clean Technol. 2018, 1, 70-88.

7. Edward, H.; Geoffrey, J.; Shi, X.; Sari, N.; Rabindra, N. The prospect for an Australian-Asian power grid: A critical appraisal. Energies 2018, 11, 200.

8. Li, Y.; Wu, M.; Li, Z. A real options analysis for renewable energy investment decisions under China carbon trading market. Energies 2018, 11, 1817. [CrossRef]

9. China State Council. The State Council's Decision to Accelerate the Cultivation and Development of Strategic Emerging Industries; National Development and Reform: Beijing, China, 2010; Volume 10, p. 10. Available online: http:/ /www.gov.cn/zwgk/2010-10/18/content_1724848.htm (accessed on 12 July 2018). 
10. China National Development and Reform Commission. Renewable Energy Development "13th Five-Year Plan"; Development and Reform Energy: Beijing, China, 2016; Volume 12, p. 10. Available online: http:/ / www.ndrcgov.cn/zcfb/zcfbtz/201612/t20161216_830264.html (accessed on 12 July 2018).

11. China Is the World's Largest Renewable Energy Investor. Available online: http:/ / www.china-nengyuan. com/news/123200.html (accessed on 11 June 2018).

12. The United Nations COMTRADE Database. Available online: https://comtrade.un.org (accessed on 11 July 2018).

13. Li, K. Chinese Government Working Report. In Proceedings of the First Meeting of the 13th National People's Congress, Beijing, China, 5 March 2018; Available online: http:/ / www.gov.cn/premier/2018-03/ 22/content_5276608.htm (accessed on 12 July 2018).

14. Dai, X.; Zhang, E. Does China's export technical complexity really catch up with developed countries? Int. Trade Issues 2011, 7, 3-16.

15. Wei, H. Re-measurement of structural changes in China's export commodities. Int. Trade Issues 2015, 4, 16-26.

16. Fan, G.; Guan, Z.; Yao, Z. Analysis of international trade structure: Technology distribution of trade products. Econ. Res. 2006, 8, 70-78.

17. Sung, B.; Wen, C. Causal dynamic relationships between political-economic factors and export performance in the renewable energy technologies market. Energies 2018, 11, 874. [CrossRef]

18. Wei, Y.; Zhang, M. Dynamic analysis of influencing factors of China's environmental products export trade-based on CMS model calculation. Int. Trade Issues 2016, 4, 107-116.

19. Zhao, Z.; Yang, H.; Zuo, J. Evolution of international trade for photovoltaic cells: A spatial structure study. Energy 2017, 124, 435-446. [CrossRef]

20. Fu, Y. Research on export competitiveness of China's renewable energy industry-based on customs data from 1998 to 2010. Res. World 2013, 6, 48-52.

21. Jiang, W.; Wang, T. An empirical study of the impact of productive subsidies on China's renewable energy enterprises exports-based on micro-enterprise panel data. Int. Econ. Trade Res. 2017, 9, 26-39.

22. Liu, M. International trade relations of renewable energy industry and China's current situation-based on spatial gravity model. China Circ. Econ. 2015, 5, 94-99.

23. Zhu, X.; He, C.; Mao, X. Spatial pattern of China's photovoltaic industry and its influencing factors under the background of trade protection. Econ. Geogr. 2018, 3, 98-105.

24. Chen, S.; Liu, X.; Chang, Q. Comparative study on technology innovation and industrial competitiveness of photovoltaic industry. J. Hebei Univ. Econ. Bus. 2016, 6, 97-100.

25. Guo, B.; Li, J.; Zhang, X. Research on the breakthrough of low-end technology locking in China's photovoltaic industry with multi-agent participation. J. Beijing Inst. Technol. Soc. Sci. Ed. 2017, 4, 18-27.

26. Li, W. On the disputes of WTO renewable energy trade and China's countermeasures. J. Shanghai Univ. Int. Bus. Econ. 2018, 1, 5-16.

27. Wang, L.; Chen, L. New convergence of Sino-US trade game: Cooperation and friction in the field of renewable energy trade. Econ. Res. Ref. 2012, 20, 3-11.

28. Tian, K.; Yang, C. Analysis of the impact of Sino-European photovoltaic trade disputes on economic profit and loss of both parties. Syst. Eng. Theory Pr. 2016, 7, 1653-1660.

29. Jiang, Z.; Gai, W. Technology innovation, industrial innovation system and value creation-based on the perspective of China's photovoltaic industry. J. Cent. South Univ. Soc. Sci. Ed. 2017, 2, 111-120.

30. Guan, Z. Looking at the strength of "Made in China" from the US market-Focusing on emerging technology products. Int. Econ. Rev. 2002, 4, 5-12.

31. Lall, S.; John, W.; Zhang, J. The sophistication of exports: A new measure of product characteristics. World Dev. 2006, 34, 222-237. [CrossRef]

32. Du, X.; Wang, W. The technology structure of China's export trade and its Changes: 1980-2003. Econ. Res. 2007, 7, 137-151.

33. Hausmann, R.; Jason, H.; Dani, R. What you export matters. J. Econ. Growth 2005, 12, 1-25. [CrossRef]

34. Wang, X.; Yang, L.; Qian, Z. Export structure transformation, technical complexity upgrade and China's manufacturing carbon emissions-From the perspective of embedding global value chains. Sankei Rev. 2017, 3, 5-18.

35. Yin, Z.; Tian, T. The change of China's agricultural products export competitiveness and international comparison-based on the analysis of the complexity of export technology. Agric. Technol. Econ. 2013, 1, 77-86. 
36. Cong, H.; Wu, F.; Zou, D. Estimation and international comparison of technology structure of China's cultural and creative products trade export. Explor. Econ. Issues 2016, 9, 85-92.

37. Tang, B. Analysis of the measurement and influencing factors of China's high-tech industry value chain status. Economics 2012, 10, 65-70.

38. Zhu, S.; Chen, Y.; Xie, R. "The competition of the dragon and elephant" and "The dance of the dragon and elephant"-An analysis of Sino-Indian trade relations based on the export technology structure. Stat. Res. 2009, 26, 25-32.

39. Huang, Y.; Zhang, W. Foreign research progress in export complexity. Int. Trade Issues 2012, 3, 167-176.

40. The World Bank Database. Available online: http:/ / databank.worldbank.org (accessed on 20 July 2018).

41. How Did Denmark Become a Wind Power Kingdom? Available online: https://www.xianjichina.com/ news/details_73133.html (accessed on 28 June 2018).

(C) 2018 by the authors. Licensee MDPI, Basel, Switzerland. This article is an open access article distributed under the terms and conditions of the Creative Commons Attribution (CC BY) license (http://creativecommons.org/licenses/by/4.0/). 